\title{
Alteromonas tagae sp. nov. and Alteromonas simiduii sp. nov., mercury-resistant bacteria isolated from a Taiwanese estuary
}

Correspondence
Wung Yang Shieh
winyang@ntu.edu.tw

\author{
Hsiu-Hui Chiu, ${ }^{1}$ Wung Yang Shieh, ${ }^{1}$ Silk Yu Lin, ${ }^{1}$ Chun-Mao Tseng, ${ }^{1,2}$ \\ Pei-Wen Chiang ${ }^{2}$ and Irene Wagner-Döbler ${ }^{3}$ \\ ${ }^{1}$ Institute of Oceanography, National Taiwan University, PO Box 23-13, Taipei, Taiwan \\ ${ }^{2}$ National Center for Ocean Research, National Taiwan University, PO Box 23-13, Taipei, \\ Taiwan \\ ${ }^{3} \mathrm{GBF}$ - Gesellschaft für Biotechnologische Forschung, Mascheroder Weg 1, D-38124 \\ Braunschweig, Germany
}

Mercury is one of the most toxic elements to all living organisms. This toxicity is due to its binding to the thiol groups of enzymes and other proteins, thereby inactivating vital cell functions (Wagner-Döbler et al., 2000). The major form of mercury in the atmosphere is elemental mercury $\left(\mathrm{Hg}^{0}\right)$, which is volatile and is oxidized to the mercuric ion $\left(\mathrm{Hg}^{2+}\right)$ as a result of its interaction with ozone in the presence of water (Munthe, 1992). Thus, most of the mercury entering the aquatic environment is $\mathrm{Hg}^{2+}$. Inorganic mercury species, $\mathrm{Hg}^{2+}$ and $\mathrm{Hg}^{0}$, present in the aquatic environment are subjected to microbiological conversion to highly toxic methyl mercury compounds that are subsequently bioaccumulated through the food chain. The health of predatory organisms at the top of the

The GenBank/EMBL/DDBJ accession numbers for the 16S rRNA gene sequences of Alteromonas tagae $\mathrm{AT} 1^{\top}$ and Alteromonas simiduii $\mathrm{AS}^{\top}{ }^{\top}$ are $\mathrm{DQ836765}$ and DQ836766, respectively. food chain, such as fish, birds and humans, is thereby threatened (Muir et al., 1999).

Mercury-resistant bacteria are usually aerobes or facultative anaerobes, which are readily isolated on a variety of media from water, soil and sediment as well as from humans and other animals (Osborn et al., 1997; Barkay et al., 2003). They play a major role in the global cycling of mercury. The mechanism of their mercury resistance is mediated by cytoplasmic mercuric reductase, which converts soluble $\mathrm{Hg}^{2+}$ to insoluble $\mathrm{Hg}^{0}$, followed by volatilization of the relatively non-toxic $\mathrm{Hg}^{0}$; the mercuric reductase is encoded by the merA gene (Silver \& Phung, 1996). Various genera such as Acinetobacter, Aeromonas, Alcaligenes, Azotobacter, Bacillus, Bacteriodes, Beijerinckia, Caulobacter, Chromobacterium, Citrobacter, Clostridium, Enterobacter, Erwinia, Escherichia, Exiguobacterium, Flavobacterium, Klebsiella, Moraxella, Morganella, Mycobacterium, Paracoccus, Proteus, Pseudoalteromonas, Pseudomonas, Rhodococcus, 
Salmonella, Serratia, Shewanella, Shigella, Staphylococcus, Streptococcus, Streptomyces, Thiobacillus, Xanthomonas and Yersinia are reported to include mercury-resistant bacteria (Ji et al., 1989; Osborn et al., 1997; Barkay et al., 2003). Among them only Pseudoalteromonas haloplanktis and some Caulobacter strains are considered to be autochthonous marine bacteria due to the requirement of $\mathrm{NaCl}$ for growth.

Two marine mercury-resistant isolates were recovered from water samples collected from the Er-Jen River estuary, Tainan, Taiwan. Polyphasic characterization data from this study indicated that the two isolates should be classified as the type strains of two novel species in the genus Alteromonas.

Polypeptone-yeast extract-mercury (PYM) broth media used for selective cultivation of mercury-resistant bacteria were made up of two parts. Part I contained 3 g polypeptone (Nihon Seiyaku), $1 \mathrm{~g}$ Bacto yeast extract (Difco), $25 \mathrm{~g} \mathrm{NaCl}$ and $2 \mathrm{~g} \mathrm{MgCl}_{2} \cdot 6 \mathrm{H}_{2} \mathrm{O}$ dissolved in $900 \mathrm{ml}$ deionized water and adjusted to $\mathrm{pH}$ 8.0. Part II contained $2.7-13.5 \mathrm{mg}$ (approximately $10-50 \mu \mathrm{mol}$ ) $\mathrm{HgCl}_{2}$ dissolved in $100 \mathrm{ml}$ deionized water. The two parts were autoclaved separately and mixed at room temperature. Other culture media used for the present study were as described by Shieh et al. (2000), while polypeptone-yeast extract (PY) broth and its derivatives were modified with $\mathrm{MgCl}_{2} \cdot 6 \mathrm{H}_{2} \mathrm{O}$ at $2 \mathrm{~g} \mathrm{l}^{-1}$ and were adjusted to $\mathrm{pH}$ 8.0.

The Er-Jen River is located in south-west Taiwan, and is notorious for severe heavy-metal pollution by some unregulated metal reclamation processing sites at the downstream area since the 1970s. Water samples that had salinities of 14.0-34.6 psu were collected from a shallow estuarine region of the river. Each sample was diluted 10fold with sterile $\mathrm{NaCl} /$ Tris buffer $(30 \mathrm{~g} \mathrm{NaCl}$ and $0.24 \mathrm{~g}$ Tris in 1 litre deionized water, $\mathrm{pH} 8.0)$. Portions $(1 \mathrm{ml})$ of the water samples and their dilutions (10- to 100 -fold) were transferred to culture tubes containing PYM broth $(10 \mathrm{ml})$. All culture tubes were incubated aerobically at $30^{\circ} \mathrm{C}$ in the dark for 7 days. Cultures that developed visible turbidity were streaked (one loopful) on PY plate medium. Individual colonies appearing on each of the plates were picked off and purified by successive streaking on PY plates. PY stab cultures of the isolates were maintained at $25^{\circ} \mathrm{C}$ under aerobic conditions. Strains $\mathrm{AT}^{\mathrm{T}}$ and $\mathrm{AS}^{\mathrm{T}}{ }^{\mathrm{T}}$, two of the isolates deposited in both the Japan Collection of Microorganisms (JCM) and the Bioresource Collection and Research Center (BCRC) as lyophilized cultures, were used for the present study.

Strains $\mathrm{AT}^{\mathrm{T}}{ }^{\mathrm{T}}$ and $\mathrm{AS} 1^{\mathrm{T}}$ were grown in PY broth at $30^{\circ} \mathrm{C}$ and at the early stationary phase were inoculated $(0.1 \mathrm{ml})$ into tubes containing $10 \mathrm{ml}$ PYM broth with approximately $44 \mu \mathrm{M} \mathrm{HgCl}{ }_{2}$, in order to determine mercury-resistant growth and mercury-reducing activity. All culture tubes were sealed with rubber stoppers and incubated statically at $30^{\circ} \mathrm{C}$. Bacterial growth was monitored daily according to $\mathrm{OD}_{600}$ readings by using a Spectronic Instruments $20 \mathrm{D}^{+}$ spectrophotometer. Before mercury measurement, the converted $\mathrm{Hg}^{0}$ remaining in each culture was removed by purging for $5 \mathrm{~min}$ with a high-purity $\mathrm{N}_{2}$ gas. Residual mercury was measured after chemical digestion with $\mathrm{BrCl}$ by UV oxidation, followed by $\mathrm{NH}_{2} \mathrm{OH}$.HCl pre-reduction and $\mathrm{SnCl}_{2}$ reduction (Bloom \& Crecelius, 1983). Total mercury analysis was carried out daily for up to 4 days by an online purge and trap system combined with flow-injection and gold amalgamation pre-concentration techniques, together with cold vapour atomic fluorescence detection (Tseng et al., 2003). Instrument calibration was performed before and during sample analysis by injection of a $\mathrm{Hg}^{0}$ vapour standard of known mass into the argon gas stream and the bubbler, a gas-liquid separator. The relative standard deviation of replicate samples, a measure of overall precision, was less than $5 \%(n=3)$. Recovery from analytical spikes averaged $100 \pm 5 \%(n=10)$. All experimental steps were in the dark when possible and were in compliance with the ultraclean techniques of Tseng et al. (2003) throughout the procedure. All data presented here represent the means of at least three replicates.

Physiological and morphological characteristics of strains $\mathrm{AT}^{\mathrm{T}}$ and $\mathrm{AS}^{\mathrm{T}}$ were determined following the established procedures described in our recent report (Jean et al., 2006a) with modifications and additional tests as described below. Haemolysis was tested by growing cells on blood-agar plates ( $6.5 \%$ sheep blood; Creative Microbiologicals) that had been spread with sterile $\mathrm{NaCl} /$ Tris buffer $(0.1 \mathrm{ml})$. Hydrolysis of chitin was tested by growth of the strains on a modified PY plate medium containing colloidal chitin (Hobel et al., 2005) at $2 \mathrm{~g} \mathrm{l}^{-1}$. Besides the cells grown in PY broth, colonies produced on PY plate medium at 20 or $28^{\circ} \mathrm{C}$ for 3 days or more were also used for observation of prosthecae and buds via transmission electron microscopy (Bouchotroch et al., 2001; Van Trappen et al., 2004). All the test cultures were incubated aerobically at $30{ }^{\circ} \mathrm{C}$ in the dark for 7 days, unless stated otherwise.

Strains $\mathrm{AT}^{\mathrm{T}}$ and $\mathrm{AS}^{\mathrm{T}}$ were cultivated aerobically in PY broth at $30^{\circ} \mathrm{C}$ in the dark for 2 days. The cultures were centrifuged to harvest cell mass for analysis. Polar lipids in the cells were extracted, purified and analysed by the methods described by Lin \& Shieh (2006). Isoprenoid quinones were extracted, purified and analysed by using an HPLC apparatus equipped with a reversed-phase column (Jean et al., 2006b). Fatty acids in whole cells grown on PY plate medium at $30^{\circ} \mathrm{C}$ for 2 days were extracted, saponified and esterified, followed by GC analysis of the fatty acid methyl esters according to the instructions of the MIDI system (Sasser, 1997). This work was performed at the BCRC, Food Industry Research and Development Institute, Taiwan. Determination of the DNA G $+\mathrm{C}$ content by HPLC analysis (Shieh \& Liu, 1996) was also performed at the BCRC.

Cells grown in PY broth at $30^{\circ} \mathrm{C}$ for 2 days were harvested by centrifugation. Extraction and purification of total genomic DNA from the cells and PCR amplification of 


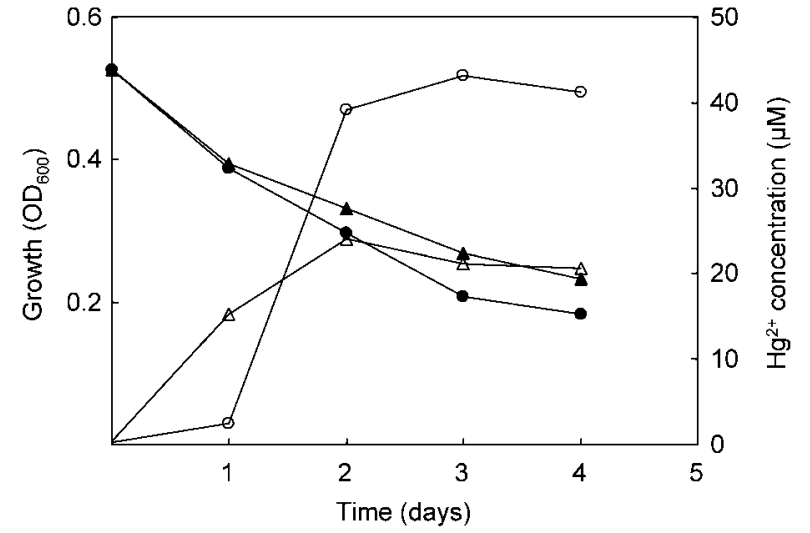

Fig. 1. Changes in $\mathrm{OD}_{600}$ (open symbols) and $\mathrm{Hg}^{2+}$ concentration (filled symbols) during growth of strains $A T 1^{\top}$ (circles) and $\mathrm{AS}^{\top}{ }^{\top}$ (triangles) in PYM broth.

16S rRNA genes followed the methods described by Jean et al. (2006a). Sequencing of the $16 \mathrm{~S}$ rRNA genes, alignment and comparison of the resulting sequences with reference sequences available in the GenBank database, calculation of distance matrices for the aligned sequences and reconstruction of phylogenetic trees by the neighbour-joining, maximum-parsimony and maximum-likelihood methods

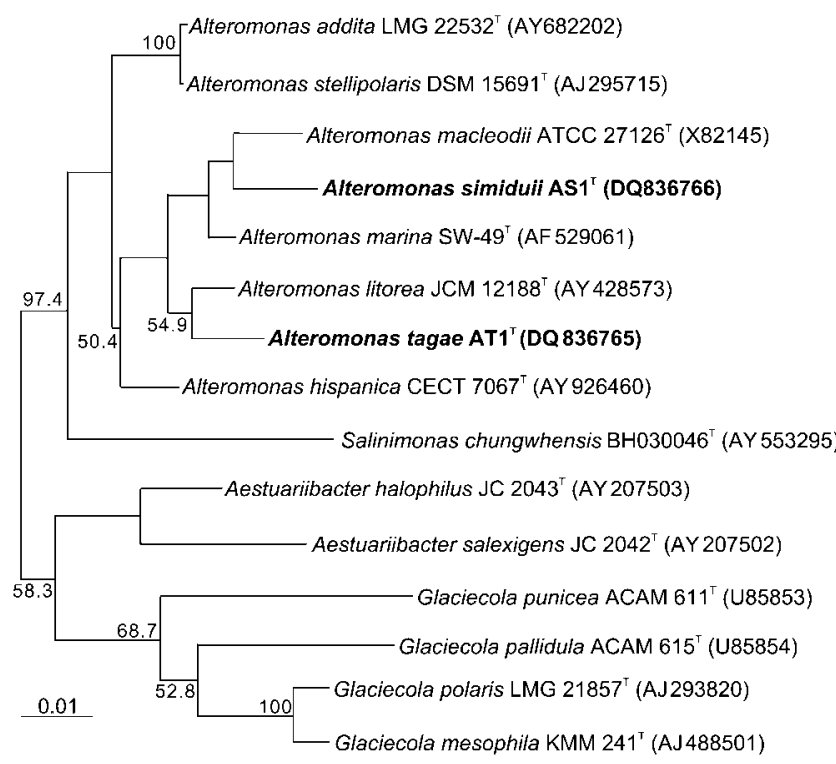

Fig. 2. Unrooted phylogenetic tree derived from neighbour-joining analysis of $16 \mathrm{~S}$ rRNA gene sequences, showing the relationship between strains $A T 1^{\top}$ and $\mathrm{AS}^{\top}$ and recognized Alteromonas species, together with related taxa belonging to the family Alteromonadaceae. GenBank accession numbers are given in parentheses. Only bootstrap values above $50 \%$ are shown at branch nodes (percentages of 1000 replications). Bar, $1 \%$ estimated sequence divergence.
Table 1. Cellular fatty acid contents (\%) of strains $A T 1^{\top}$ and $\mathrm{AS}^{\top}$ and type strains of recognized Alteromonas species

Strains: $1, \operatorname{ATl}^{\mathrm{T}}$ (data from this study); $2, \mathrm{AS1}^{\mathrm{T}}$ (this study); $3, A$. addita R10SW $13^{\mathrm{T}}$ (Ivanova et al., 2005); 4, A. hispanica F-32 ${ }^{\mathrm{T}}$ (Martínez-Checa et al., 2005); 5, A. litorea TF-22 ${ }^{\mathrm{T}}$ (Yoon et al., 2004); 6, A. macleodii DSM 6062 ${ }^{\mathrm{T}}$ (Yoon et al., 2003); 7, A. marina SW- $47^{\mathrm{T}}$ (Yoon et al., 2003); 8, A. stellipolaris ANT $69 \mathrm{a}^{\mathrm{T}}$ (Van Trappen et al., 2004). -, Not detected/not reported; tr, trace amount detected $(<1 \%)$.

\begin{tabular}{|c|c|c|c|c|c|c|c|c|}
\hline Fatty acid & 1 & 2 & 3 & 4 & 5 & 6 & 7 & 8 \\
\hline $\mathrm{C}_{10: 0} 3-\mathrm{OH}$ & 1.5 & $\operatorname{tr}$ & 3.3 & 1.2 & 1.4 & 1.5 & 1.3 & - \\
\hline $\mathrm{C}_{11: 0}$ & $\operatorname{tr}$ & $\operatorname{tr}$ & - & - & - & - & - & - \\
\hline $\mathrm{C}_{11: 0} 3-\mathrm{OH}$ & 1.6 & $\operatorname{tr}$ & 2.5 & - & 1.2 & - & 1.0 & - \\
\hline iso- $\mathrm{C}_{11: 0} 3-\mathrm{OH}$ & $\operatorname{tr}$ & $\operatorname{tr}$ & 2.2 & - & - & - & - & - \\
\hline $\mathrm{C}_{12: 0}$ & 2.9 & 2.9 & 1.0 & 1.8 & 2.7 & 2.5 & 2.9 & - \\
\hline iso- $\mathrm{C}_{12: 0}$ & $\operatorname{tr}$ & - & - & - & - & - & - & - \\
\hline iso- $\mathrm{C}_{12: 0} 3-\mathrm{OH}$ & $\operatorname{tr}$ & - & 1.1 & - & - & - & - & - \\
\hline $\mathrm{C}_{12: 0} 3-\mathrm{OH}$ & 1.2 & 1.5 & 1.9 & 1.1 & 1.1 & 1.2 & 1.1 & - \\
\hline $\mathrm{C}_{12: 1} 3-\mathrm{OH}$ & $\operatorname{tr}$ & - & - & - & - & - & - & - \\
\hline $\mathrm{C}_{13: 0}$ & $\operatorname{tr}$ & $\operatorname{tr}$ & $\operatorname{tr}$ & - & - & - & - & - \\
\hline iso- $\mathrm{C}_{13: 0}$ & - & $\operatorname{tr}$ & - & - & - & - & - & - \\
\hline anteiso- $\mathrm{C}_{13: 0}$ & $\operatorname{tr}$ & $\operatorname{tr}$ & - & - & - & - & - & - \\
\hline $\mathrm{C}_{14: 0}$ & 2.4 & 5.7 & 2.9 & 2.1 & 3.6 & 2.5 & 2.6 & - \\
\hline iso- $\mathrm{C}_{14: 0}$ & $\operatorname{tr}$ & $\operatorname{tr}$ & $\operatorname{tr}$ & - & - & - & - & - \\
\hline $\mathrm{C}_{14: 0} 3-\mathrm{OH}$ & - & - & 2.9 & - & - & - & - & - \\
\hline $\mathrm{C}_{14: 1}$ & - & - & 1.9 & - & - & - & - & - \\
\hline $\mathrm{C}_{15: 0}$ & - & - & 1.8 & - & 2.1 & 2.5 & 2.8 & - \\
\hline $\mathrm{C}_{15: 0} 3-\mathrm{OH}$ & - & - & 1.2 & - & - & - & - & - \\
\hline anteiso- $\mathrm{C}_{15: 0}$ & $\operatorname{tr}$ & $\operatorname{tr}$ & - & - & - & - & - & - \\
\hline $\mathrm{C}_{15: 1} \omega 6 c$ & $\operatorname{tr}$ & - & - & - & - & - & - & - \\
\hline $\mathrm{C}_{15: 1} \omega 8 c$ & 1.6 & 1.5 & 2.7 & - & 1.0 & 1.7 & 1.1 & - \\
\hline$C_{16: 0}$ & 19.0 & 22.7 & 15.2 & 13.8 & 20.0 & 23.8 & 21.2 & 12.6 \\
\hline iso- $\mathrm{C}_{16: 0}$ & 1.0 & 1.0 & $\operatorname{tr}$ & - & - & 1.1 & - & - \\
\hline $\mathrm{C}_{16: 0} 3-\mathrm{OH}$ & - & $\operatorname{tr}$ & 1.4 & - & - & - & - & $\operatorname{tr}$ \\
\hline $\mathrm{C}_{16: 0} \mathrm{~N}$ alcohol & 1.2 & $\operatorname{tr}$ & - & 7.4 & 5.6 & 6.6 & 3.2 & $\operatorname{tr}$ \\
\hline $\mathrm{C}_{16: 1} \omega 7 c$ alcohol & $\operatorname{tr}$ & - & 30.1 & 1.2 & 5.8 & 4.3 & 1.9 & $\operatorname{tr}$ \\
\hline $\mathrm{C}_{17: 0}$ & 8.2 & 2.0 & 2.0 & - & 2.9 & 2.6 & 3.2 & - \\
\hline 10-Methyl $\mathrm{C}_{17: 0}$ & $\operatorname{tr}$ & $\operatorname{tr}$ & - & 15.6 & 4.5 & 2.9 & 1.5 & - \\
\hline iso- $\mathrm{C}_{17: 0}$ & - & $\operatorname{tr}$ & - & - & - & - & - & - \\
\hline anteiso- $\mathrm{C}_{17: 0}$ & $\operatorname{tr}$ & $\operatorname{tr}$ & - & - & - & - & - & - \\
\hline $\mathrm{C}_{17: 1} \omega 6 c$ & $\operatorname{tr}$ & - & - & - & - & - & - & - \\
\hline $\mathrm{C}_{17: 1} \omega 8 c$ & 9.4 & 4.5 & 4.1 & - & 3.6 & 4.3 & 5.6 & 9.4 \\
\hline $\mathrm{C}_{18: 0}$ & 2.1 & $\operatorname{tr}$ & 1.0 & 5.9 & - & - & - & - \\
\hline $\mathrm{C}_{18: 1} \omega 7 c$ & 11.7 & 11.3 & 11.7 & 14.3 & 12.5 & 9.9 & 11.8 & 18.0 \\
\hline $\mathrm{C}_{18: 1} \omega 9 c$ & $\operatorname{tr}$ & - & - & - & - & - & - & - \\
\hline iso- $\mathrm{C}_{18: 0}$ & $\operatorname{tr}$ & $\operatorname{tr}$ & 7.8 & - & - & - & - & - \\
\hline 11-Methyl $\mathrm{C}_{18: 1} \omega 7 c$ & - & $\operatorname{tr}$ & - & - & - & - & - & - \\
\hline $\mathrm{C}_{18: 3} \omega 6 c(6,9,12)$ & - & - & - & 5.0 & - & - & - & - \\
\hline $\mathrm{C}_{13: 0} 3-\mathrm{OH} /$ iso- $\mathrm{C}_{15: 1}$ & - & $\operatorname{tr}$ & - & - & - & - & - & - \\
\hline $\begin{array}{l}\text { iso- } \mathrm{C}_{15: 0} 2-\mathrm{OH} / \\
\mathrm{C}_{16: 1} \omega 7 c\end{array}$ & 22.4 & 33.7 & - & 22.1 & 20.0 & 24.6 & 28.5 & 27.3 \\
\hline $\begin{array}{l}\text { iso- } \mathrm{C}_{16: 1} \mathrm{I} / \mathrm{C}_{14: 0} \\
3-\mathrm{OH}\end{array}$ & 3.9 & - & - & 2.6 & 3.0 & 3.3 & 3.6 & - \\
\hline
\end{tabular}



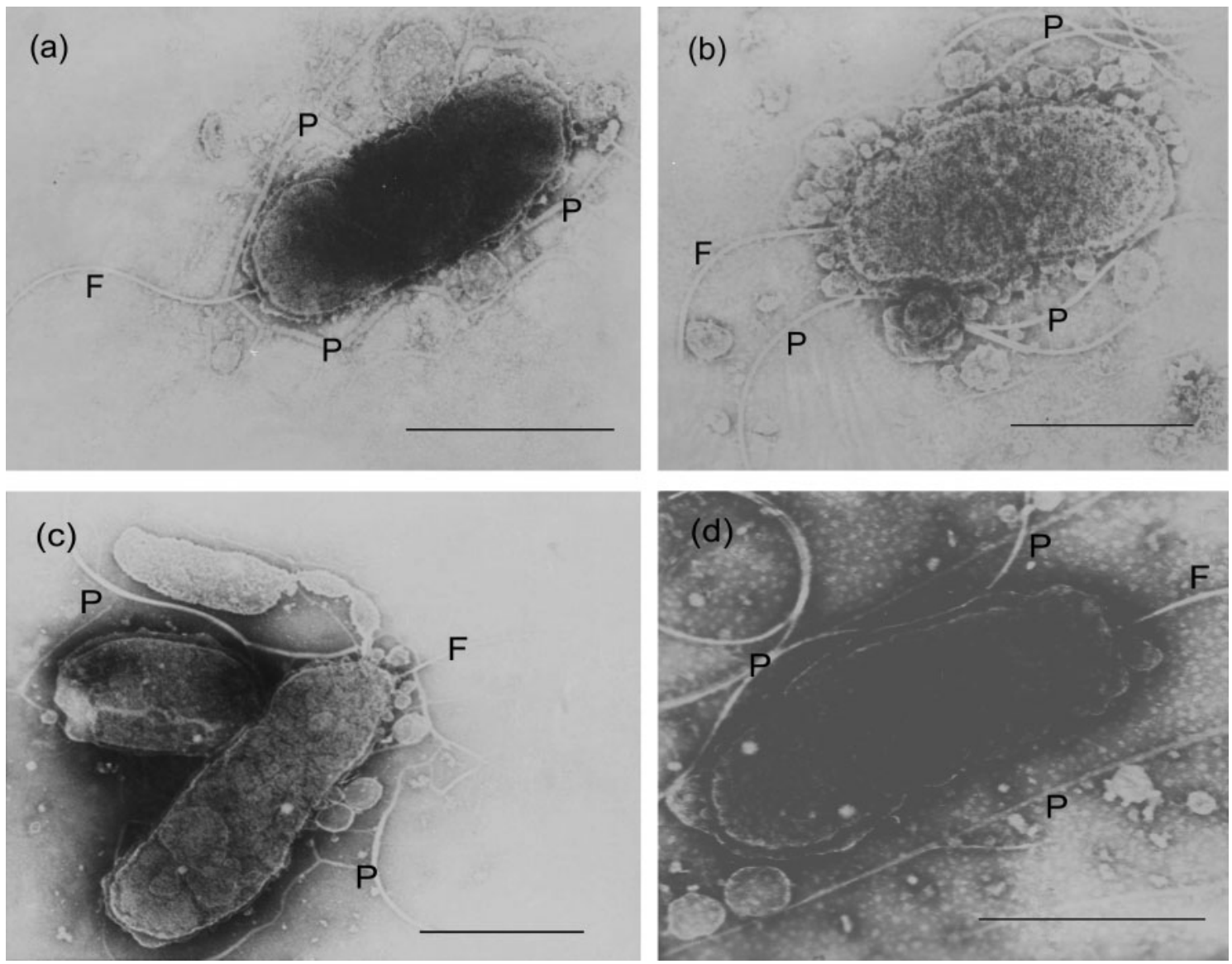

Fig. 3. Electron micrographs of negatively stained preparations of cells of strains $A T 1^{\top}(a, b)$ and $A S 1^{\top}$ (c, $\left.d\right)$, showing prosthecae $(P)$, flagella $(F)$ and bleb-like structures. Cells used for analysis were grown on PY plate medium at $20^{\circ} \mathrm{C}$ for 4 days $(\mathrm{a}, \mathrm{c})$ or in PY broth at $30^{\circ} \mathrm{C}$ for 3 days $(b, d)$. Bars, $1 \mu \mathrm{m}$.

were performed as described in our recent reports (Shieh et al., 2004; Jean et al., 2006a). The stability of clusters was evaluated by a bootstrap analysis of 1000 replications.

Strains $\mathrm{AT}^{\mathrm{T}}$ and $\mathrm{AS}^{\mathrm{T}}$ grew in PY broth over a $\mathrm{pH}$ range of $6-9$, and most rapidly at $\mathrm{pH} 7-8$. No growth was observed at $\mathrm{pH}$ 5. The two strains grew in PY broth over a temperature range of $15-40{ }^{\circ} \mathrm{C}$, with an optimum at about $30^{\circ} \mathrm{C}$. Only strain $\mathrm{AS}^{\mathrm{T}}$ grew at $10^{\circ} \mathrm{C}$ within $15-20$ days of incubation. Neither of the strains grew at 4 or $42-45^{\circ} \mathrm{C}$. The two strains were halophilic bacteria that grew well in PY broth at $\mathrm{NaCl}$ levels of $0.5-12 \%$ (maximal $\mathrm{OD}_{600}>0.5$ ), with optimum growth at $2-4 \% \mathrm{NaCl}$. No growth was observed at 0 or $14-15 \% \mathrm{NaCl}$. Strain $\mathrm{AT}^{\mathrm{T}}$ grew at $13 \% \mathrm{NaCl}$ within 5-10 days of incubation (maximal $\mathrm{OD}_{600}>0.3$ ) but strain $\mathrm{AS}^{\mathrm{T}}$ did not; weak growth was observed for strain $\mathrm{AS}^{\mathrm{T}}$ after incubation for $15-20$ days (maximal $\mathrm{OD}_{600}<0.1$ ). Strains $\mathrm{AS}^{\mathrm{T}}{ }^{\mathrm{T}}$ and $\mathrm{AT} 1^{\mathrm{T}}$ were mercury-resistant bacteria. They grew significantly in PYM broth containing $\mathrm{HgCl}_{2}$ at an initial concentration of about $44 \mu \mathrm{M}$. Mercury-resistant growth was accompanied by a rapid decrease in $\mathrm{Hg}^{2+}$ concentration $(>20 \mu \mathrm{M})$ within 3 days (Fig. 1). Strains $\mathrm{AT}^{\mathrm{T}}$ and $\mathrm{AS}^{\mathrm{T}}$ could have reduced $\mathrm{Hg}^{2+}$ to $\mathrm{Hg}^{0}$ during this growth.
The 16S rRNA gene sequences that had been determined for strains $\mathrm{AT}^{\mathrm{T}}$ and $\mathrm{AS}^{\mathrm{T}}$ comprised 1479 and $1391 \mathrm{nt}$, respectively. They were aligned and compared with all bacterial sequences available in the GenBank database. The two sequences shared $94.6 \%$ sequence similarity (75 differences out of $1391 \mathrm{nt}$ positions). The signature nucleotides present in the family Alteromonadaceae (Ivanova et al., 2004), 304 (A), 734 (A), 736 (T), 770 (T) and 809 (A), were also present in these sequences. Moreover, phylogeny based on neighbour-joining analysis of $16 \mathrm{~S}$ rRNA gene sequences revealed that the closest neighbours of strains $\mathrm{AT}^{\mathrm{T}}$ and $\mathrm{AS1}^{\mathrm{T}}$ were species of the genus Alteromonas in the family Alteromonadaceae (Fig. 2). Similar results were obtained with the maximum-parsimony and maximum-likelihood algorithms (data not shown). Strains $\mathrm{AT}^{\mathrm{T}}{ }^{\mathrm{T}}$ and $\mathrm{AS}^{\mathrm{T}}$ showed, respectively, 93.9-95.8 and 95.3-96.8 \% 16S rRNA gene sequence similarity to the type strains of the six recognized Alteromonas species. The next closest neighbours of strains $\mathrm{AT}^{\mathrm{T}}$ and $\mathrm{AS}^{\mathrm{T}}$ were species of the genera Aestuariibacter (90.5-93.5\% sequence similarity) and Salinimonas $(91.5-91.7 \%)$ in the family Alteromonadaceae. No other species shared more than $91 \%$ sequence similarity with the two novel strains. 

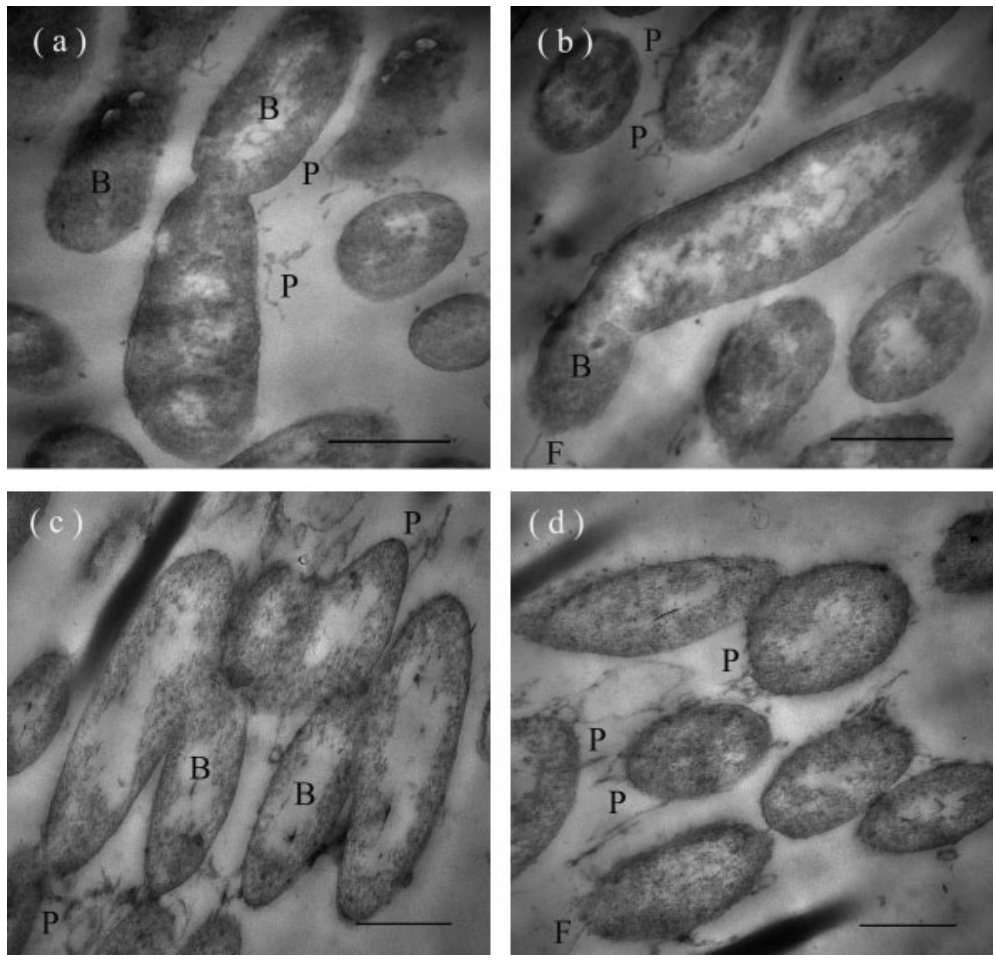

Fig. 4. Electron micrographs of thin-section preparations of cells of strains $\mathrm{AT}^{\top}{ }^{\top}(a, b)$ and $\mathrm{AS}^{\top}(\mathrm{c}, \mathrm{d})$, showing buds $(\mathrm{B})$, prosthecae $(P)$ and flagella $(F)$. Cells used for analysis were grown on $P Y$ plate medium at $28^{\circ} \mathrm{C}$ for 4 days. Thin-section preparations were stained with $1 \%$ uranyl acetate and $10 \%$ lead citrate. Bars, $0.5 \mu \mathrm{m}$.

The DNA G + C contents of strains $\mathrm{AT}^{\mathrm{T}}(43.1 \mathrm{~mol} \%)$ and $\mathrm{AS1}^{\mathrm{T}}$ (45.3 mol\%) fell within the range of reported values for recognized Alteromonas species (43.0-46.4 mol\%). The two novel strains, like most other members of the genus Alteromonas, contained $\mathrm{C}_{16: 0}(19.0-22.7 \%), \mathrm{C}_{16: 1} \omega 7 c$ and/ or iso- $\mathrm{C}_{15: 0} 2-\mathrm{OH}(22.4-33.7 \%$; the two fatty acids could not be differentiated in the MIDI system) and $\mathrm{C}_{18: 1} \omega 7 c$ $(11.3-11.7 \%)$ as the major cellular fatty acids. The remaining cellular fatty acids are listed in Table 1. Quantitative differences in the fatty acids can be used to differentiate the two strains from recognized species of the genus Alteromonas despite the different cultivation conditions used. The polar lipids of strain $\mathrm{AT}^{\mathrm{T}}$ consisted of phosphatidylethanolamine (46.6\%), phosphatidylglycerol $(28.9 \%)$ and sulfolipid $(24.5 \%)$, whereas in strain $\mathrm{AS}^{\mathrm{T}}$ they consisted of phosphatidylethanolamine $(48.2 \%)$ and phosphatidylglycerol (51.8\%). Some Alteromonas species, such as Alteromonas addita and Alteromonas macleodii, were also found to have phosphatidylethanolamine and phosphatidylglycerol as major polar lipids (Ivanova et al., 2000, 2005). Strains $\mathrm{AT}^{\mathrm{T}}{ }^{\mathrm{T}}$ and $\mathrm{AS}^{\mathrm{T}}{ }^{\mathrm{C}}$ contained Q-8 as the predominant isoprenoid quinone $\left(99.9 \%\right.$ for $\mathrm{AT}^{\mathrm{T}}$ and $91.3 \%$ for $\left.\mathrm{AS1}^{\mathrm{T}}\right)$, but only AS1 ${ }^{\mathrm{T}}$ contained Q-4 $(4.3 \%)$ and Q-6 (4.3\%). Q-8 was detected as the predominant isoprenoid quinone in Alteromonas hispanica (96.5\%; Martínez-Checa et al., 2005), Alteromonas macleodii ( $92 \%$; Yoon et al., 2003), Alteromonas marina ( $94 \%$; Yoon et al., 2003) and Alteromonas litorea (Yoon et al., 2004). However, Q-4 and Q-6 have not been detected in these Alteromonas species.
The genus Alteromonas has been shown to include prosthecate, budding bacteria (Van Trappen et al., 2004; Martínez-Checa et al., 2005). Both strains $\mathrm{AT}^{\mathrm{T}}$ and $\mathrm{AS}^{\mathrm{T}}$ were also found to produce buds and prosthecae (Figs 3 and 4). They shared many other phenotypic characteristics. The two, however, could be differentiated from each other by different colony types and by different reactions in tests for hydrolysis of casein, lecithin and starch, activity of cystine arylamidase and $\alpha$-galactosidase, reduction of nitrate to nitrite, growth at $10^{\circ} \mathrm{C}$, growth on $\mathrm{D}$-fructose as a sole carbon and energy source and sensitivity to the vibriostatic agent $\mathrm{O} / 129$.

Phylogeny based on 16S rRNA genes and data from chemotaxonomic studies support the establishment of two novel species in the genus Alteromonas to accommodate the two novel strains described here. The names Alteromonas tagae sp. nov. and Alteromonas simiduii sp. nov. are proposed, with $\mathrm{AT1}^{\mathrm{T}}$ and $\mathrm{AS1}^{\mathrm{T}}$ as the respective type strains. Table 2 shows characteristics that are useful for differentiation between the two novel species and the other recognized species of the genus Alteromonas. Detailed characterization data are given below in the species descriptions.

The present study has provided the first evidence that the genus Alteromonas includes mercury-resistant species. Alteromonas tagae and Alteromonas simiduii have thus far been found only in saline estuarine water. These species may readily occur in other saline habitats, given that they can grow over rather wide ranges of temperatures and salinities and do not require organic growth factors. 
Table 2. Characteristics that differentiate strains $A T 1^{\top}$ and $A S 1^{\top}$ from recognized species of the genus Alteromonas

Strains: 1, $\mathrm{AT}^{\mathrm{T}}$ (data from this study); 2, $\mathrm{AS}^{\mathrm{T}}$ (this study); 3, A. addita R10SW13 ${ }^{\mathrm{T}}$ (Ivanova et al., 2005); 4, A. hispanica $\mathrm{F}-32^{\mathrm{T}}$ (Martínez-Checa et al., 2005); 5, A. litorea TF-22 ${ }^{\mathrm{T}}$ (Yoon et al., 2004); 6, A. macleodii DSM 6062 ${ }^{\mathrm{T}}$ (unless indicated, data from Bowman \& McMeekin, 2005); 7, A. marina SW $-47^{\mathrm{T}}$ (Yoon et al., 2003); 8, A. stellipolaris ANT 69a ${ }^{\mathrm{T}}$ (Van Trappen et al., 2004). +, Positive; -, negative; W, weakly positive; ND, no data available. Cells of all strains are Gram-negative rods, motile by means of a polar flagellum, and require $\mathrm{NaCl}$ for growth, grow at $15-37^{\circ} \mathrm{C}$ and $\mathrm{pH} 6-9$ and are positive for oxidase and catalase.

\begin{tabular}{|c|c|c|c|c|c|c|c|c|}
\hline Characteristic & 1 & 2 & 3 & 4 & 5 & 6 & 7 & 8 \\
\hline Cream-coloured colonies & + & - & - & + & + & - & + & + \\
\hline Buds/prosthecae & + & + & ND & + & ND & + & + & + \\
\hline Poly- $\beta$-hydroxybutyrate accumulation & + & + & - & + & ND & - & ND & - \\
\hline \multicolumn{9}{|l|}{ Growth at/in: } \\
\hline $4{ }^{\circ} \mathrm{C}$ & - & - & + & + & - & - & + & + \\
\hline $10^{\circ} \mathrm{C}$ & - & + & + & + & + & + & + & + \\
\hline $40^{\circ} \mathrm{C}$ & + & + & - & + & + & + & + & - \\
\hline $42^{\circ} \mathrm{C}$ & - & - & - & - & + & ND & + & - \\
\hline $3 \% \mathrm{NaCl}$ & + & + & + & - & + & ND & + & + \\
\hline $13 \% \mathrm{NaCl}$ & + & $\mathrm{W}$ & - & + & + & $\mathrm{ND}$ & + & - \\
\hline $15 \% \mathrm{NaCl}$ & - & - & - & + & - & $\mathrm{ND}$ & + & - \\
\hline Nitrate reduction to nitrite & - & + & - & - & - & - & - & - \\
\hline Haemolysis & - & - & + & - & ND & ND & ND & - \\
\hline \multicolumn{9}{|l|}{ Hydrolysis of: } \\
\hline Agar & - & - & $\mathrm{w}$ & - & - & - & - & - \\
\hline Casein & + & - & $\mathrm{ND}$ & + & + & $\mathrm{ND}$ & + & $\mathrm{ND}$ \\
\hline Lecithin & + & - & - & - & ND & ND & ND & ND \\
\hline Starch & + & - & + & + & + & + & + & + \\
\hline $\mathrm{H}_{2} \mathrm{~S}$ from cysteine & - & - & - & + & - & ND & - & - \\
\hline \multicolumn{9}{|l|}{ Acid from: } \\
\hline D-Glucose & - & - & ND & - & - & $(+)^{*}$ & - & - \\
\hline D-Maltose & - & - & ND & + & + & $(+)$ & - & $\mathrm{ND}$ \\
\hline Sucrose & - & - & $\mathrm{ND}$ & - & - & $(+)$ & + & $\mathrm{W}$ \\
\hline D-Trehalose & - & - & $\mathrm{ND}$ & - & + & $(+)$ & + & $\mathrm{ND}$ \\
\hline \multicolumn{9}{|l|}{ Growth on: } \\
\hline D-Cellobiose & + & + & + & - & $\mathrm{ND}$ & + & $\mathrm{ND}$ & + \\
\hline D-Fructose & - & + & + & - & + & + & + & + \\
\hline D-Galactose & + & + & - & - & + & + & + & + \\
\hline D-Glucose & + & + & - & - & ND & + & $\mathrm{ND}$ & + \\
\hline D-Lactose & + & + & + & - & + & + & + & - \\
\hline D-Mannitol & - & - & - & + & - & + & - & + \\
\hline L-Serine & + & + & - & - & $\mathrm{ND}$ & - & $\mathrm{ND}$ & - \\
\hline L-Lactate & + & + & + & - & - & + & - & - \\
\hline$\beta$-Hydroxybutyrate & + & + & + & ND & ND & - & ND & + \\
\hline D-Sorbitol & - & - & + & - & - & - & - & - \\
\hline D-Mannose & - & - & + & - & ND & - & ND & + \\
\hline D-Ribose & + & + & ND & ND & ND & - & $\mathrm{ND}$ & - \\
\hline D-Melezitose & + & + & ND & - & ND & - & ND & ND \\
\hline \multicolumn{9}{|l|}{ API ZYM test results: } \\
\hline Cystine arylamidase & - & + & ND & ND & - & - & - & - \\
\hline$\alpha$-Galactosidase & - & + & ND & ND & - & - & - & $\mathrm{w}$ \\
\hline $\mathrm{O} / 129$ sensitivity $(150 \mu \mathrm{g})$ & + & - & $\mathrm{ND}$ & $\mathrm{ND}$ & $\mathrm{ND}$ & $\mathrm{ND}$ & $\mathrm{ND}$ & ND \\
\hline DNA $\mathrm{G}+\mathrm{C}$ content $(\mathrm{mol} \%)$ & 43.1 & 45.3 & 43.0 & 46.3 & 46.0 & $44.9-46.4$ & $44.0-45.0$ & $43.0-45.0$ \\
\hline
\end{tabular}

${ }^{*}$ Data in parentheses are from Yoon et al. (2003). 


\section{Description of Alteromonas tagae sp. nov.}

Alteromonas tagae (ta'gae. N.L. gen. n. tagae of Taga, named after Nobuo Taga, a pioneering Japanese marine microbiologist).

Cells are Gram-negative rods $(1.2-2.5 \times 0.5-0.9 \mu \mathrm{m})$ that are motile by means of a single polar flagellum. Colonies produced on PY agar plates at $30{ }^{\circ} \mathrm{C}$ for $72-96 \mathrm{~h}$ are approximately $2.0-3.5 \mathrm{~mm}$ in diameter, cream-coloured, opaque, of low convexity and non-luminescent, with somewhat undulatory edges. Swarming does not occur. Buds and prosthecae are commonly produced on cells grown on PY agar plates at 20 or $28{ }^{\circ} \mathrm{C}$ for $3-7$ days; these structures can also be observed on cells grown in PY broth at $30{ }^{\circ} \mathrm{C}$ for 3-7 days. Extracellular bleb-like structures are produced. Endospores are absent. Chemo-organotroph capable of respiratory, but not fermentative, metabolism. Sodium ions are required for growth; growth occurs at $\mathrm{NaCl}$ levels of $0.5-13 \%$, with an optimum at $2-4 \%$ and no growth at 0 or $14-15 \% \mathrm{NaCl}$. Growth occurs at $15-40{ }^{\circ} \mathrm{C}$, with optimum growth at about $30^{\circ} \mathrm{C}$; no growth at $4-10$ or $42-45^{\circ} \mathrm{C}$. Able to grow over a $\mathrm{pH}$ range of $6-9$ but not at $\mathrm{pH}$ 5. Acid is not produced from oxidation or fermentation of the following carbohydrates: D-glucose, D-arabinose, Larabinose, D-cellobiose, D-galactose, D-lactose, D-maltose, D-mannose, D-melibiose, sucrose, D-trehalose, D-xylose, dulcitol, inositol or D-mannitol. Able to reduce $\mathrm{Hg}^{2+}$ to $\mathrm{Hg}^{0}$. Poly- $\beta$-hydroxybutyrate is accumulated as an intracellular reserve product. Negative for denitrification and haemolysis tests. Nitrate is not reduced to nitrite. Indole is not produced from tryptophan. $\mathrm{H}_{2} \mathrm{~S}$ is not produced from thiosulfate. Oxidase and catalase are present, but arginine dihydrolase, lysine decarboxylase and ornithine decarboxylase are absent. Aesculin, alginate, casein, DNA, gelatin, lecithin, starch, and Tweens 20 and 80 are hydrolysed but agar, chitin and urea are not. Able to grow on the following compounds as sole carbon and energy sources: D-cellobiose, D-glucose, D-galactose, D-lactose, D-melezitose, D-melibiose, D-ribose, sucrose, D-trehalose, glycerol, acetate, $\beta$ hydroxybutyrate, L-lactate, L-alanine, L-glutamic acid and Lthreonine. Unable to grow on the following compounds as sole carbon and energy sources: D-arabinose, L-arabinose, D-fructose, D-mannose, D-xylose, dulcitol, inositol, Dmannitol, D-sorbitol, citrate, fumarate, malonate, tartrate and D-arginine. The following constitutive enzyme activities are detected in API ZYM tests: leucine arylamidase, valine arylamidase, esterase (C4), esterase lipase (C8), lipase (C14), acid phosphatase, alkaline phosphatase and naphthol-ASBI-phosphohydrolase. Polar lipids comprise phosphatidylethanolamine $(46.6 \%)$, phosphatidylglycerol $(28.9 \%)$ and sulfolipid $(24.5 \%)$. Q-8 is the only isoprenoid quinone $(99.9 \%)$ but trace amounts of some others may also occur. Cellular fatty acids present at levels greater than $3 \%$ include $\mathrm{C}_{16: 1} \omega 7 c$ and/or iso- $\mathrm{C}_{15: 0} 2-\mathrm{OH}(22.4 \%), \mathrm{C}_{16: 0}(19.0 \%)$, $\mathrm{C}_{18: 1} \omega 7 c(11.7 \%), \mathrm{C}_{17: 1} \omega 8 c(9.4 \%), \mathrm{C}_{17: 0}(8.2 \%)$, and iso- $\mathrm{C}_{16: 1} \mathrm{I}$ and/or $\mathrm{C}_{14: 0} 3-\mathrm{OH}(3.9 \%)$. Sensitive to the vibriostatic agent $\mathrm{O} / 129$ at $150 \mu \mathrm{g}$. Susceptible to ampicillin $(10 \mu \mathrm{g})$, chloramphenicol $(30 \mu \mathrm{g})$, colistin $(10 \mu \mathrm{g})$, carbenicillin $(100 \mu \mathrm{g})$, erythromycin $(15 \mu \mathrm{g})$, gentamicin $(10 \mu \mathrm{g})$, kanamycin $(30 \mu \mathrm{g})$, nalidixic acid $(30 \mu \mathrm{g})$, neomycin $(30 \mu \mathrm{g})$, novobiocin $(30 \mu \mathrm{g})$, polymyxin $\mathrm{B}(300 \mathrm{U})$, streptomycin $(10 \mu \mathrm{g})$ and tetracycline $(30 \mu \mathrm{g})$, and intermediately susceptible to vancomycin $(30 \mu \mathrm{g})$. Resistant to cephalothin $(30 \mu \mathrm{g})$, clindamycin $(2 \mu \mathrm{g})$, lincomycin $(2 \mu \mathrm{g})$, oxacillin $(1 \mu \mathrm{g})$ and penicillin $\mathrm{G}(10 \mathrm{U})$. The DNA $\mathrm{G}+\mathrm{C}$ content is $43.1 \mathrm{~mol} \%$.

The type strain, $\mathrm{AT}^{\mathrm{T}}\left(=\mathrm{BCRC} 17571^{\mathrm{T}}=\mathrm{JCM} 13895^{\mathrm{T}}\right)$, was isolated from a water sample collected at the estuary of the Er-Jen River, Tainan, Taiwan.

\section{Description of Alteromonas simiduii sp. nov.}

Alteromonas simiduii (si.mi'du.i.i. N.L. gen. n. simiduii of Simidu, named after Usio Simidu, a Japanese microbiologist, for his work on marine microbiology).

Description is as for the species description of Alteromonas tagae with the following differences. Cells are $1.2-2.5 \mu \mathrm{m}$ long and $0.4-0.8 \mu \mathrm{m}$ wide. Colonies produced on PY agar plates at $30^{\circ} \mathrm{C}$ for $72-96 \mathrm{~h}$ are approximately $1-3 \mathrm{~mm}$ in diameter, off-white, translucent, umbonate and nonluminescent, with somewhat undulatory edges. Growth occurs in PY broth at $10^{\circ} \mathrm{C}$ within $15-20$ days incubation. Growth occurs at $\mathrm{NaCl}$ levels of $0.5-13 \%$; growth is slow and weak at $13 \% \mathrm{NaCl}$. Casein, lecithin and starch are not hydrolysed. D-Fructose can be utilized as a sole carbon and energy source for growth. Nitrate is reduced to nitrite. Cystine arylamidase and $\alpha$-galactosidase are present in API ZYM tests. Polar lipids comprise phosphatidylethanolamine $(48.2 \%)$ and phosphatidylglycerol $(51.8 \%)$. Isoprenoid quinones comprise Q-8 (91.3\%), Q-4 (4.3\%) and Q-6 $(4.3 \%)$. Cellular fatty acids present at levels greater than $3 \%$ include $\mathrm{C}_{16: 1} \omega 7 c$ and/or iso- $\mathrm{C}_{15: 0} 2-\mathrm{OH}(33.7 \%), \mathrm{C}_{16: 0}$ $(22.7 \%), \mathrm{C}_{18: 1} \omega 7 c(11.3 \%), \mathrm{C}_{14: 0}(5.7 \%)$ and $\mathrm{C}_{17: 1} \omega 8 c$ $(4.5 \%)$. Resistant to the vibriostatic agent $\mathrm{O} / 129$ at $150 \mu \mathrm{g}$. Resistant to vancomycin $(30 \mu \mathrm{g})$. The DNA G $+\mathrm{C}$ content is $45.3 \mathrm{~mol} \%$.

The type strain, $\mathrm{AS}^{\mathrm{T}}{ }^{\mathrm{T}}\left(=\mathrm{BCRC} 17572^{\mathrm{T}}=\mathrm{JCM} 13896^{\mathrm{T}}\right)$, was isolated from a water sample collected at the estuary of the Er-Jen River, Tainan, Taiwan.

\section{Acknowledgements}

We are grateful to Dr J.-S. Chen for advice and critical reading of the manuscript. This study was supported by grants NSC91-2313-B-002327, NSC92-2313-B-002-084 and NSC94-2313-B-002-066 from the National Science Council, Taiwan.

\section{References}

Barkay, T., Miller, S. M. \& Summers, A. O. (2003). Bacterial mercury resistance from atoms to ecosystems. FEMS Microbiol Rev 27, 355-384.

Bloom, N. S. \& Crecelius, E. A. (1983). Determination of mercury in seawater at sub-nanogram per liter levels. Mar Chem 14, 49-59. 
Bouchotroch, S., Quesada, E., del Moral, A., Llamas, I. \& Béjar, V. (2001). Halomonas maura sp. nov., a novel moderately halophilic, exopolysaccharide-producing bacterium. Int J Syst Evol Microbiol 51, 1625-1632.

Bowman, J. P. \& McMeekin, T. A. (2005). Genus I. Alteromonas Baumann, Baumann, Mandel and Allen 1972, 418, emend. Gauthier, Gauthier and Christen 1995a, 760. In Bergey's Manual of Systematic Bacteriology, 2nd edn, vol. 2, part B, pp. 444-447. Edited by D. J. Brenner, N. R. Krieg, J. T. Staley \& G. M. Garrity. New York: Springer.

Hobel, C. F. V., Marteinsson, V. T., Hreggvidsson, G. O. \& Kristjansson, J. K. (2005). Investigation of the microbial ecology of intertidal hot springs by using diversity analysis of $16 \mathrm{~S}$ rRNA and chitinase genes. Appl Environ Microbiol 71, 2771-2776.

Ivanova, E. P., Zhukova, N. V., Svetashev, V. I., Gorshkova, N. M., Kurilenko, V. V., Frolova, G. M. \& Mikhailov, V. V. (2000). Evaluation of phospholipid and fatty acid compositions as chemotaxonomic markers of Alteromonas-like Proteobacteria. Curr Microbiol 41, 341-345.

Ivanova, E. P., Flavier, S. \& Christen, R. (2004). Phylogenetic relationships among marine Alteromonas-like proteobacteria: emended description of the family Alteromonadaceae and proposal of Pseudoalteromonadaceae fam. nov., Colwelliaceae fam. nov., Shewanellaceae fam. nov., Moritellaceae fam. nov., Ferrimonadaceae fam. nov., Idiomarinaceae fam. nov. and Psychromonadaceae fam. nov. Int J Syst Evol Microbiol 54, 1773-1788.

Ivanova, E. P., Bowman, J. P., Lysenko, A. M., Zhukova, N. V., Gorshkova, N. M., Sergeev, A. F. \& Mikhailov, V. V. (2005). Alteromonas addita sp. nov. Int J Syst Evol Microbiol 55, 1065-1068.

Jean, W. D., Shieh, W. Y. \& Chiu, H.-H. (2006a). Pseudidiomarina taiwanensis gen. nov., sp. nov., a marine bacterium isolated from shallow coastal water of An-Ping Harbour, Taiwan, and emended description of the family Idiomarinaceae. Int J Syst Evol Microbiol 56, 899-905.

Jean, W. D., Chen, J.-S., Lin, Y.-T. \& Shieh, W. Y. (2006b). Bowmanella denitrificans gen. nov., sp. nov., a denitrifying bacterium isolated from seawater from An-Ping Harbour, Taiwan. Int J Syst Evol Microbiol 56, 2463-2467.

Ji, G., Salzberg, S. P. \& Silver, S. (1989). Cell-free mercury volatilization activity from three marine Caulobacter strains. Appl Environ Microbiol 55, 523-525.

Lin, Y.-T. \& Shieh, W. Y. (2006). Zobellella denitrificans gen. nov., sp. nov. and Zobellella taiwanensis sp. nov., denitrifying bacteria capable of fermentative metabolism. Int J Syst Evol Microbiol 56, 1209-1215.
Martínez-Checa, F., Bejar, V., Llamas, I., del Moral, A. \& Quesada, E. (2005). Alteromonas hispanica sp. nov., a polyunsaturated-fatty-acidproducing, halophilic bacterium isolated from Fuente de Piedra, southern Spain. Int J Syst Evol Microbiol 55, 2385-2390.

Muir, D., Braune, B., DeMarch, B., Norstrom, R., Wagemann, R., Lockhart, L., Hargrave, B., Bright, D., Addison, R. \& other authors (1999). Spatial and temporal trends and effects of contaminants in the Canadian Arctic marine ecosystem: a review. Sci Total Environ 230, 83-144.

Munthe, J. (1992). Aqueous oxidation of elemental mercury by ozone. Atmos Environ 26A, 1461-1468.

Osborn, A. M., Bruce, K. D., Strike, P. \& Ritchie, D. A. (1997). Distribution, diversity, and evolution of the bacterial mercury resistance (mer) operon. FEMS Microbiol Rev 19, 239-262.

Sasser, M. (1997). Identification of bacteria by gas chromatography of cellular fatty acids. MIDI Technical Note 101. Newark, DE: MIDI Inc.

Shieh, W. Y. \& Liu, C. M. (1996). Denitrification by a novel halophilic fermentative bacterium. Can J Microbiol 42, 507-514.

Shieh, W. Y., Chen, A. L. \& Chiu, H. H. (2000). Vibrio aerogenes sp. nov., a facultatively anaerobic marine bacterium that ferments glucose with gas production. Int J Syst Evol Microbiol 50, 321-329.

Shieh, W. Y., Lin, Y.-T. \& Jean, W. D. (2004). Pseudovibrio denitrificans gen. nov., sp. nov., a marine, facultatively anaerobic, fermentative bacterium capable of denitrification. Int J Syst Evol Microbiol 54, 2307-2312.

Silver, S. \& Phung, L. T. (1996). Bacterial heavy metal resistance: new surprise. Annu Rev Microbiol 50, 753-789.

Tseng, C.-M., Balcom, P. H., Lamborg, C. H. \& Fitzgerald, W. F. (2003). Dissolved elemental mercury investigations in Long Island Sound using on-line $\mathrm{Au}$ amalgamation-flow injection analysis. Environ Sci Technol 37, 1183-1188.

Van Trappen, S., Tan, T.-L., Yang, J., Mergaert, J. \& Swings, J. (2004). Alteromonas stellipolaris sp. nov., a novel, budding, prosthecate bacterium from Antarctic seas, and emended description of the genus Alteromonas. Int J Syst Evol Microbiol 54, 1157-1163.

Wagner-Döbler, I., von Canstein, H. F., Li, Y., Timmis, K. N. \& Deckwer, W.-D. (2000). Removal of mercury from chemical wastewater by microorganisms in technical scale. Environ Sci Technol 34, 4628-4634.

Yoon, J.-H., Kim, I.-G., Kang, K. H., Oh, T.-K. \& Park, Y.-H. (2003). Alteromonas marina sp. nov., isolated from sea water of the East Sea in Korea. Int J Syst Evol Microbiol 53, 1625-1630.

Yoon, J.-H., Yeo, S.-H., Oh, T.-K. \& Park, Y.-H. (2004). Alteromonas litorea sp. nov., a slightly halophilic bacterium isolated from an intertidal sediment of the Yellow Sea in Korea. Int J Syst Evol Microbiol 54, 1197-1201. 